STUDIA PRAWNO-EKONOMICZNE, T. CXV, 2020

PL ISSN 0081-6841; e-ISSN 2450-8179 $\quad$ s. 283-305

https://doi.org/10.26485/SPE/2020/115/16

\title{
Katarzyna LORENTOWICZ*
}

iD https://orcid.org/0000-0003-0510-6763

\section{Sławomir KALINOWSKI**}

iD https://orcid.org/0000-0002-8068-4312

\section{Weronika WYDUBA***}

iD https://orcid.org/0000-0003-4091-5574

\section{FINANSOWANIE WIEJSKICH ORGANIZACJI POZARZADOWYCH}

\begin{abstract}
Abstrakt
Przedmiot badań: Organizacje pozarządowe tworzą trzeci sektor gospodarki obok sektora publicznego i prywatnego. Nie są nastawione na zysk, jednak muszą czynnie poszukiwać źródeł finansowania swojej działalności.

Cel badawczy: Celem artykułu jest identyfikacja czynników, które są odpowiedzialne za sprawność finansowania organizacji pozarządowych na podstawie analizy źródeł finansowania organizacji pozarządowych na wsi w porównaniu z miastem.

Metoda badawcza: W części teoretycznej omówiono pojęcie trzeciego sektora, podstawy prawne jego funkcjonowania, specyfikę organizacji pozarządowych prowadzących działalność na wsi oraz organizacji pożytku publicznego. W części empirycznej poddano weryfikacji hipotezy badawcze, zakładające zależność wielkości przychodów oraz wyniku finansowego od posiadania przez NGOs statusu OPP, ich doświadczenia, liczby oraz dywersyfikacji źródeł przychodów. Podstawą analiz empirycznych jest badanie ankietowe.

Wyniki: Udowodniono hipotezy zakładające zależność wysokości przychodów organizacji pozarządowych od dywersyfikacji źródeł finansowania, posiadania statusu OPP oraz między wynikiem finansowym a zwiększaniem zainteresowania nowymi możliwościami poszukiwania przychodów. Nie udało się natomiast udowodnić hipotezy zakładającej zależność pomiędzy doświadczeniem organizacji (mierzonej długością prowadzonej działalności) a wielkością przychodów.
\end{abstract}

Słowa kluczowe: trzeci sektor, organizacje pozarządowe, źródła finansowania.

Klasyfikacja JEL: D6, D64, I3

* Specjalista ds. księgowości, Stowarzyszenie Na Tak; e-mail: k.lorentowicz@gmail.com

** Dr hab., prof. IRWIR PAN, Instytut Rozwoju Wsi i Rolnictwa PAN, Zakład Ekonomii Wsi; e-mail: skalinowski@irwirpan.waw.pl

*** Mgr, Instytut Rozwoju Wsi i Rolnictwa PAN, Zakład Ekonomii Wsi; e-mail: wwyduba@ irwirpan.waw.pl 


\section{Wstęp}

We współczesnej gospodarce trzeci sektor odgrywa niezwykle ważną rolę społeczną i ekonomiczną. Jest jednym z ważniejszych aktorów w sferze publicznej ${ }^{1}$. Stanowi nie tylko punkt wyjścia współczesnych demokracji, ale jest istotą realizacji celów społecznie użytecznych. Nie jest to jednak aktywność substytucyjna w stosunku do działań państwa oraz rynku, a powinna stanowić jej uzupełnienie, w myśl zasady pierwszeństwa celów społecznych nad gospodarczymi. Non-profitowy system działania organizacji nie zwalnia ich jednak z konieczności starania się o środki, zatem muszą one też mieć podejście ekonomiczne czy też quasi-ekonomiczne. Warto jednak podkreślić, że podejście to nie może być oceniane przez pryzmat osiąganych zysków, a także, a może przede wszystkim poprzez działania związane ze wzajemnością i solidarnością, które są trudne do wyjaśnienia na gruncie ekonomii neoklasycznej². Niemniej jednak podmioty te muszą starać się o środki na realizację swych celów statutowych. Warunkiem ich efektywnego działania są odpowiednie zasoby zarówno finansowe, jak i rzeczowe. Konieczne są zatem poszukiwania i identyfikacja źródeł finansowania instytucji. W szczególności ważne są instytucje trzeciego sektora na obszarach wiejskich, gdzie zarówno poziom, jak i jakość życia są relatywnie gorsze. I chociaż na wsi zauważalne są procesy gentryfikacyjne ${ }^{3}$, to nadal istnieje znaczna grupa wymagająca pomocy. W tym też zakresie działalność instytucji trzeciego sektora jest niezbędna.

1 U. Grzelońska, Rola sektora non profit $w$ polskiej gospodarce, Studia Ekonomiczne 2011/4, s. 326 (325-344); Z. Galor, S. Kalinowski, T. Kujaczyński, Rola ekonomii pomocy $w$ przeciwdziałaniu kluczowemu działaniu $w$ globalizacji, Roczniki Ekonomiczne Kujawsko-Pomorskiej Szkoły Wyższej w Bydgoszczy 2013/6, s. 91-104; D. Moroń, Trzeci sektor $w$ teorii wielosektorowej polityki społecznej, Wrocławskie Studia Politologiczne 2013/15, s. 7-17; T. Dyczkowski, Wptyw źródet finansowania na planowanie i kontrole $w$ organizacjach korzystajacych z pomocy publicznej, Prace Naukowe Uniwersytetu Ekonomicznego we Wrocławiu 2016/424, s. 72-85; T. Marcysiak, P. Prus, Life strategies of rural inhabitants of unfixed economic function, Pro-ceedings of the 26th International Scientific Conference Agrarian Perspectives XXVI "Competi-tiveness of European Agriculture and Food Sectors", Czech University of Life Sciences Prague, Faculty of Economics and Management 2017, s. 212-218; P. Salustowicz, Soziale Arbeit und Empowerment - einige kritische Bemerkungen zur Suche nach einer politischen Sozialen Arbeit, w: K. Böller, P. Hansbauer, B. Hansenjürgen, S. Langenohl (Hrsg.), Die Produktivität des Sozialen - den sozialen Staat aktivieren, VS Verlag für Sozialwis - senschaften, Wiesbaden, s. 187-196.

2 S. Kalinowski, Ekonomia społeczna?, w: Dylematy współczesnej polityki społecznej, Z warsztatu badawczego Katedry Nauk Społecznych. Rok dziewiąty, Poznań 2007, s. 20-29.

3 D. Zwęglińska-Galecka, Gentryfikacja wsi i jej zasięg, Wieś i Rolnictwo 2019/183/2, s. 57-87. 
Funkcjonowanie podmiotów trzeciego sektora ma określone ramy instytucjonalne i prawne uwarunkowania prowadzonej przez nich działalności ${ }^{4}$. Perspektywa prawno-instytucjonalna koncentruje się na analizie prawnych i organizacyjnych aspektów funkcjonowania tych organizacji, pomijając ich stronę finansową. Próbując wyjść naprzeciw tym wyzwaniom, za cel artykułu postawiono identyfikację czynników, które są odpowiedzialne za sprawność finansowania organizacji pozarządowych na wsi, a także analizę ich źródeł finansowania. Aby zrealizować powyższy cel, sformułowano problem badawczy i hipotezy. Głównym problemem badawczym było pytanie, w jaki sposób specyfika funkcjonowania trzeciego sektora wpływa na wyniki finansowe i budowę potencjału ekonomicznego organizacji.

Sformułowano również cztery hipotezy badawcze, które zostały następnie poddane weryfikacji statystycznej:

1. Wysokość przychodów organizacji pozarządowej zależy od posiadania statusu OPP;

2. Wynik finansowy organizacji pozarządowej zależy od zmiany liczby źródeł przychodów w stosunku do roku poprzedniego;

3. Przychody organizacji pozarządowej zależą od dywersyfikacji źródeł przychodów;

4. Przychody organizacji pozarządowej zależą od okresu aktywności.

Hipotezy te uszczegóławiają problem, odnosząc wzrost wyniku finansowego i przychodów podmiotów trzeciego sektora do takich zjawisk, jak doświadczenie na rynku, dywersyfikacja źródeł finansowania czy posiadanie statusu organizacji pożytku publicznego.

\section{Znaczenie organizacji pozarządowych w gospodarce}

W języku polskim funkcjonuje wiele nazw organizacji trzeciego sektora, jednak wszystkie odnoszą się do tego samego podmiotu (schemat 1).

4 Ustawa z dnia 7 kwietnia 1989 r. - Prawo o stowarzyszeniach, z późniejszymi zmianami, Dz.U. z 2019 r., poz. 713; Ustawa z dnia 6 kwietnia 1984 r. o fundacjach, z późniejszymi zmianami, Dz.U. z 2018 r., poz. 1491; Ustawa z dnia 24 kwietnia 2003 r. o działalności pożytku publicznego i o wolontariacie, z późniejszymi zmianami, Dz.U. z 2019 r., poz. 688. 
SCHEMAT 1: Nazwy organizacji pozarzadowych funkcjonujace w literaturze

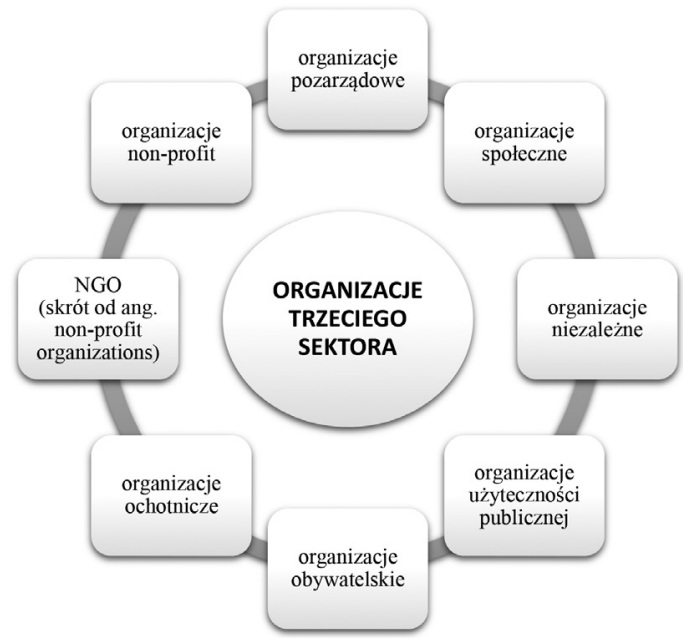

Źródło: opracowanie własne na podstawie portalu organizacji pozarządowych www.ngo.pl; stan na 2.12.2019 r.

Termin trzeci sektor traktowany jest w literaturze zamiennie $\mathrm{z}$ nazwą organizacje pozarządowe lub non-profit, włączając $\mathrm{w}$ to pojęcie wszystkie podmioty o charakterze instytucjonalnym uważane na mocy obowiązujących przepisów prawa za organizacje pozarządowe ${ }^{5}$. Trzeci sektor obejmuje także organizacje samorządowe, które spełniają kryteria organizacji pozarządowej, lecz działają na mocy odrębnych przepisów ${ }^{6}$. Do trzeciego sektora, obok podmiotów mających formalny status organizacji pozarządowych, zaliczane są także nieformalne grupy ${ }^{7} \mathrm{i}$ w tym rozumieniu pojęcie trzeci sektor nie jest tożsame $\mathrm{z}$ organizacją pozarządową. Zakres pojęciowy trzeciego sektora jest poszerzany przez włączenie do niego również spółdzielni i towarzystw ubezpieczeń wzajemnych oraz innych przedsiębiorstw społecznych ${ }^{8}$. W tym rozumieniu organizacji non-

5 J. Schmidt, Rozwój organizacji pozarządowych. Teoria i praktyka, Wydawnictwo Akademickie Sedno, Warszawa 2012, s. 15.

6 E. Leś, S. Nalęcz, Potencjat ekonomiczny i społeczny sektora non-profit w Polsce. Wybrane wyniki badań międzynarodowych sektora non-profit, w: P. Gliński, B. Lewenstein, A. Siciński (red.), Samoorganizacja społeczeństwa polskiego: trzeci sektor, Wydawnictwo Instytutu Filozofii i Socjologii PAN, Warszawa 2002, s. 13-31.

7 E. Bogacz-Wojtanowska, Zarzadzanie organizacjami pozarzadowymi na przykładzie stowarzyszeń krakowskich, Wydawnictwo Uniwersytetu Jagiellońskiego, Kraków 2006, s. 27-28.

8 K. Kietlińska, Rola trzeciego sektora w społeczeństwie obywatelskim, Wydawnictwo Difin, Warszawa 2010, s. 91. 
-profit trzeci sektor tworzą również organizacje z zakresu gospodarki społecznej o charakterze biznesowym, które przynoszą zysk, jednakże nie dystrybuują go w całości, lecz rozdzielają pomiędzy członków lub przeznaczają na cele społeczne' ${ }^{9}$ W tej najszerszej perspektywie pojęcie trzeciego sektora nie stanowi synonimu terminu organizacja pozarządowa. Powstają kontrowersje wynikające z niejednoznacznego określenia zakresu instytucji trzeciego sektora, ponieważ zalicza się do niego podmioty o bardzo zróżnicowanych formach organizacyjno-prawnych, a trudności terminologiczne, związane z bogatym nazewnictwem stosowanym w odniesieniu do organizacji i sektora non-profit, stwarzają dodatkowo niejasności interpretacyjne. W niniejszym opracowaniu pojęcie „organizacje pozarządowe" będzie stosowane zamiennie z nazwą „organizacje non-profit” oraz terminem „organizacje użyteczności publicznej”.

Z perspektywy ekonomicznej organizacje non-profit znajdują się pomiędzy państwem a rynkiem, uzyskując charakter instytucji uzupełniających, jednak nie alternatywnych ${ }^{10}$. W realizacji usług publicznych mają one przewagę ekonomiczną, ponieważ swoją działalność opierają na pracy wolontariuszy (niskie koszty pracy) oraz wsparciu darczyńców ${ }^{11}$. Linia podziału oddzielająca organizacje pozarządowe od pozostałych sektorów gospodarki jest nieostra, co wynika w głównej mierze z uwarunkowań prawnych (schemat 2).

Miejsce trzeciego sektora przedstawił W.A. Ninacs ${ }^{12}$, który wpisał go w obszar instytucji gospodarki społecznej (biały obszar), będący uzupełnieniem instytucji znajdujących się poza sferą gospodarki społecznej (ciemnoszary obszar) i grup pośrednich (jasnoszary obszar), które mają cechy typowo nastawione na zysk i trudno je zaliczyć do trzeciego sektora (schemat 3). Miejsce instytucji non-profit w czterowymiarowym prostokącie Ninacsa odpowiada społecznym kryteriom ich funkcjonowania oraz pozarynkowej aktywności gospodarczej. Próbując wpisać te instytucje w struktury organizacyjne i powiązane z nimi typy struktur stowarzyszeniowych, należałoby podejść indywidualnie do każdej z organizacji, szukając, które z nich są mniej lub bardziej sformalizowane oraz które są w większym lub mniejszym stopniu regulowane organizacyjnie.

9 W. Kaczocha, J. Sikora, Gospodarcze społeczeństwo obywatelskie-podmioty ekonomii spotecznej, Studia Oeconomica Posnaniensia 2015/7, s. 57-71.

10 K. Lorentowicz, S. Kalinowski, W. Wyduba, Syntetyczny wskaźnik finansowania organizacji pożytku publicznego, Handel Wewnętrzny 2018/6 (377)/I, s. 273-286.

11 J. Hausner, Organizacje pozarządowe-trzeci sektor współczesnego społeczeństwa, Zeszyty Naukowe Akademii Ekonomicznej w Krakowie 2006/714, s. 5-21.

12 W.A. Ninacs, A Review of the Theory and Practice of Social Economy, SRDC Working Paper Series 2002/02/02, s. 7. 
SCHEMAT 2: Miejsce trzeciego sektora $w$ gospodarce

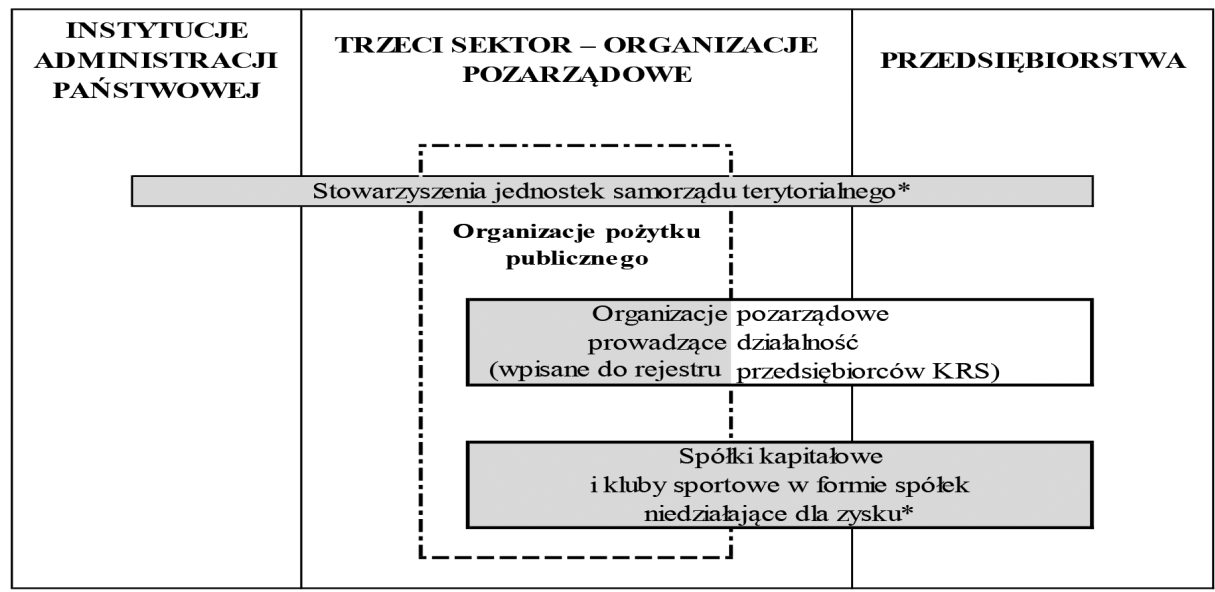

Objaśnienia:

* organizacje zrównane z pozarządowymi na mocy art. 3 ust. 2 Ustawy z dnia 24 kwietnia 2003 r. o działalności pożytku publicznego i o wolontariacie.

Źr ódło: opracowanie własne.

SCHEMAT 3: Miejsce instytucji spolecznych $w$ gospodarce

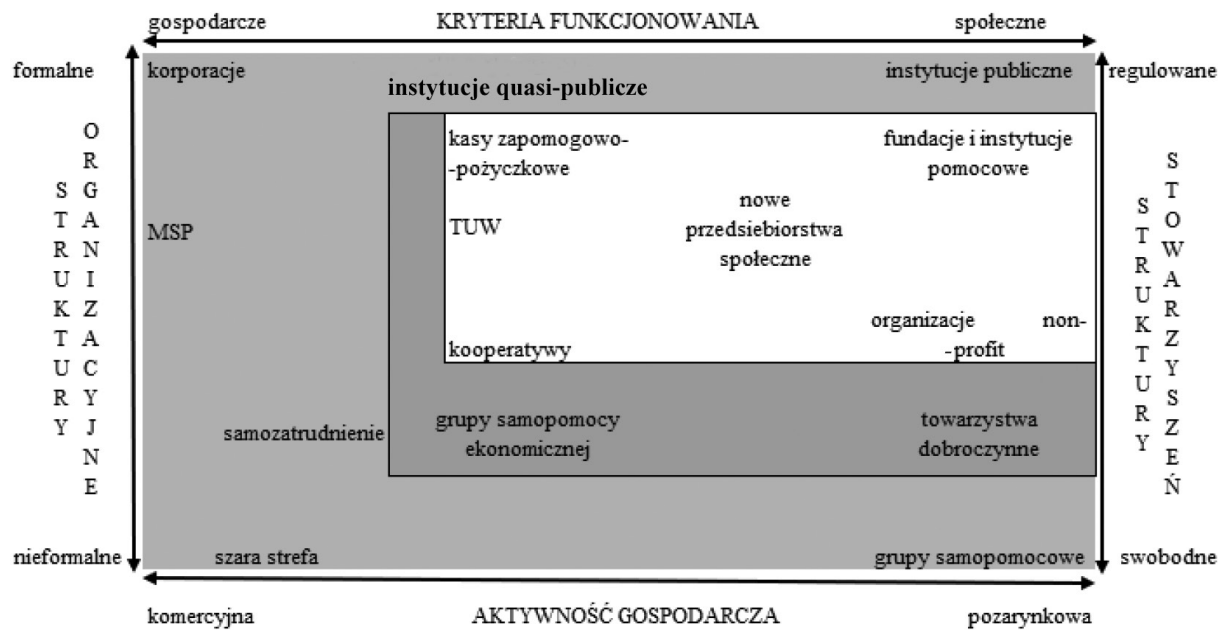

Źr ó d ł o: W.A. Ninacs, A Review of the Theory and Practice of Social Economy, SRDC Working Paper Series 2002/02/02, s. 7. 
Należy zwrócić uwagę, że organizacje pozarządowe mogą prowadzić działalność gospodarczą, a przejawem marketyzacji (urynkowienie sektora publicznego) sektora NGO jest także prowadzenie przez organizacje pozarządowe działalności ekonomicznej w formie spółki z ograniczoną odpowiedzialnością czy spółdzielni socjalnej ${ }^{13}$. Konsekwencją ,ekonomizacji” trzeciego sektora jest uczestnictwo organizacji pozarządowych w rynku, co sytuuje je na styku trzeciego sektora i sektora przedsiębiorstw.

\section{Metodyka badań}

Źródła finansowania organizacji pozarządowych na terenach wiejskich zidentyfikowano na podstawie przeprowadzonych badań ankietowych. Ankiety przesłano do 511 organizacji pozarządowych z całej Polski z siedzibami na terenach wiejskich. Kwestionariusze dostarczono drogą elektroniczną w trzech turach (w kolejnych turach nie były uwzględniane organizacje, od których otrzymano już odpowiedź zwrotną). Ostatecznie w badaniu wzięło udział 87 organizacji pozarządowych, co stanowi około $17 \%$ wszystkich podmiotów poproszonych o wypełnienie ankiety.

Oszacowano istotność badanych zależności i obliczono współczynniki korelacji dla związków istotnych statystycznie. W badaniu wykorzystano również pytania dotyczące opinii o współpracy z otoczeniem zewnętrznym organizacji. Odpowiedzi umieszczono na 5-stopniowej skali Likerta, które następnie opracowano za pomocą metody dyferencjału semantycznego.

\section{Charakterystyka próby badawczej}

Wśród wszystkich przebadanych organizacji 42,5\% (37 podmiotów) posiadało status organizacji pożytku publicznego. Organizacje biorące udział w badaniu przyporządkowano do 6 grup różniących się od siebie statusem prawno-organizacyjnym (tabela 1). Najliczniejszą grupę stanowiły stowarzyszenia

13 J. Hausner, N. Laurisz, Czynniki krytyczne tworzenia przedsiębiorstw spolecznych. Przedsiębiorstwo społeczne. Konceptualizacja, w: J. Hausner (red.), Przedsiębiorstwa spoleczne w Polsce. Teoria i praktyka, Wydawnictwo Małopolska Szkoła Administracji Publicznej Uniwersytetu Ekonomicznego w Krakowie, Kraków 2008, s. 17; E. Bogacz-Wojtanowska, Istota i podstawowe zasady funkcjonowania organizacji pozarzadowych, w: E. Bogacz-Wojtanowska, S. Wrona (red.), Zarzadzanie organizacjami pozarzadowymi, Wydawnictwo Instytutu Spraw Publicznych Uniwersytetu Jagiellońskiego, Kraków 2016, s. 11-29. 
(56,32\%), następnie fundacje (ponad 16\%) oraz kluby i związki sportowe $(13,79 \%)$. Ponadto w badaniu wzięli udział przedstawiciele jednego kółka rolniczego, sześciu jednostek ochotniczej straży pożarnej oraz pięciu kół gospodyń wiejskich.

TABELA 1: Struktura udziału poszczególnych organizacji w badaniu wedtug formy organizacyjno-prawnej $(n=87)$

\begin{tabular}{|c|c|c|c|c|c|c|}
\hline $\begin{array}{c}\text { Rodzaj } \\
\text { organizacji }\end{array}$ & $\begin{array}{c}\text { Stowarzy- } \\
\text { szenie }\end{array}$ & Fundacja & $\begin{array}{c}\text { Klub/ } \\
\text { Związek } \\
\text { sportowy }\end{array}$ & $\begin{array}{c}\text { Koło } \\
\text { Gospodyń } \\
\text { Wiejskich }\end{array}$ & $\begin{array}{c}\text { Ochotni- } \\
\text { cza Straż } \\
\text { Pożarna }\end{array}$ & $\begin{array}{c}\text { Kółko } \\
\text { rolnicze }\end{array}$ \\
\hline $\begin{array}{c}\text { Udział pro- } \\
\text { centowy }\end{array}$ & 56,32 & 16,09 & 13,79 & 6,9 & 5,75 & 1,15 \\
\hline
\end{tabular}

Źró dło: opracowanie własne.

Podmioty poddane badaniu przyporządkowano do 12 grup z uwagi na obszar aktywności (tabela 2). Najwyższy odsetek (ponad 17\%) obejmował organizacje, których głównych przedmiotem zainteresowania jest rozwój lokalny. Duży udział (ok. 16\%) stanowią jednostki zajmujące się sportem i rekreacją oraz pomocą dla osób niepełnosprawnych.

TABELA 2: Obszary aktywności badanych organizacji użyteczności publicznej

\begin{tabular}{|l|c|c|}
\hline \multirow{2}{*}{$\begin{array}{c}\text { Główny obszar aktywności badanych } \\
\text { organizacji }\end{array}$} & \multicolumn{2}{|c|}{ Liczba organizacji } \\
\cline { 2 - 3 } & wartości bezwzględne & udział procentowy \\
\hline Rozwój lokalny & 2 & 3 \\
\hline $\begin{array}{l}\text { Pomoc dla osób wykluczonych } \\
\text { społecznie i zawodowo }\end{array}$ & 6 & 6,90 \\
\hline Sport i rekreacja & 15 & 16,24 \\
\hline Aktywizacja kobiet wiejskich & 6 & 6,90 \\
\hline Pomoc dla osób niepełnosprawnych & 14 & 16,09 \\
\hline $\begin{array}{l}\text { Rozwój obszarów wiejskich, } \\
\text { ekologia }\end{array}$ & 7 & 8,05 \\
\hline Edukacja & 7 & 8,05 \\
\hline
\end{tabular}




\begin{tabular}{|l|c|c|}
\hline \multicolumn{1}{|c|}{1} & 2 & 3 \\
\hline Kultura & 6 & 6,90 \\
\hline $\begin{array}{l}\text { Ochrona przeciwpożarowa i jej } \\
\text { popularyzacja }\end{array}$ & 5 & 5,75 \\
\hline Opieka nad zwierzętami & 1 & 1,15 \\
\hline Zaangażowanie obywatelskie & 3 & 3,45 \\
\hline Ochrona zdrowia & 3 & 3,45 \\
\hline Suma & 87 & 100,00 \\
\hline
\end{tabular}

Źródło: opracowanie własne.

Znaczny odsetek (8\%) organizacji wykazuje rozwój obszarów wiejskich i edukację jako główny obszar swojej aktywności. Spośród badanych tylko jeden podmiot prowadzi działalność w obszarze opieki nad zwierzętami.

Analiza struktury wieku organizacji wskazuje, że ok. 14\% z nich rozpoczęło swoją działalność jeszcze przed transformacją ustrojową w Polsce (tabela 3). Pozostałe podmioty biorące udział w badaniu powstały po roku 2005, czyli w momencie, gdy Polska znajdowała się już w Unii Europejskiej.

TABELA 3: Struktura wieku badanych organizacji

\begin{tabular}{|l|c|c|c|c|}
\hline Data rozpoczęcia działalności & do 1989 & $1990-2004$ & $2005-2012$ & $2013-2016$ \\
\hline Udział procentowy & 13,79 & 35,63 & 35,63 & 14,94 \\
\hline
\end{tabular}

Źródło: opracowanie własne.

Organizacje pożytku publicznego, które wzięły udział w badaniu, zrzeszały łącznie 4366 członków. Wśród 73 organizacji typu stowarzyszeniowego maksymalna liczba członków wyniosła 500 osób, natomiast minimalna 10 osób. Średnia liczba członków w badanej próbie wyniosła 59 osób, przy błędzie standardowym 9,14\%, natomiast mediana 37 osób. Wśród badanych organizacji o charakterze stowarzyszeniowym najczęściej występują podmioty zrzeszające 18 członków. 
TABELA 4: Statystyka opisowa liczby członków organizacji typu stowarzyszeniowego

Liczba członków

\begin{tabular}{lrlr}
\hline Średnia & 59,80 & Skośność & 3,68 \\
Błąd standardowy & 9,14 & Zakres & 490 \\
Mediana & 37 & Minimum & 10 \\
Tryb & 18 & Maksimum & 500 \\
Odchylenie standardowe & 78,10 & Suma & 4366 \\
Wariancja próbki & 6100,51 & Licznik & 73 \\
Kurtoza & 15,86 & Poziom ufności $(95,0 \%)$ & 18,22 \\
\hline
\end{tabular}

Źródło: opracowanie własne.

Blisko połowa $(49,42 \%)$ badanych organizacji realizuje swoje zadania przy pomocy zatrudnionych pracowników. W większości jednak przypadków zatrudnienie następuje jedynie w oparciu o umowę zlecenie. Stosunek pracy na podstawie umowy o pracę zawiązuje ok. $16 \%$ organizacji zatrudniających pracowników. Blisko $40 \% \mathrm{z}$ tych jednostek przewiduje zatrudnienie zarówno w oparciu o umowę zlecenie, jak i umowę o pracę (tabela 5).

TABELA 5: Formy zatrudnienia $w$ badanych NGOs

\begin{tabular}{|c|c|c|c|}
\hline Forma zatrudnienia & $\begin{array}{c}\text { Jedynie umowy } \\
\text { o pracę }\end{array}$ & $\begin{array}{c}\text { Jedynie umowy } \\
\text { zlecenie }\end{array}$ & $\begin{array}{c}\text { Oba rodzaje } \\
\text { zatrudnienia }\end{array}$ \\
\hline Udział procentowy & 16,28 & 44,19 & 39,53 \\
\hline
\end{tabular}

Źródło: opracowanie własne.

Ankietowane organizacje angażowały w swoją działalność w 2016 r. łącznie 575 pracowników. W badanych podmiotach pracowało od 1 do 81 osób (średnio 13 pracowników, przy błędzie standardowym 2,96\%). Statystycznie ujmując, najczęściej uczestnicy badania korzystali z współpracy z czterema zatrudnionymi pracownikami (tabela 6). 
TABELA 6: Statystyka opisowa liczby pracowników

Zatrudnienie

\begin{tabular}{lrlr}
\hline Średnia & 13,37209 & Skośność & 2,471359 \\
Błąd standardowy & 2,963234 & Zakres & 80 \\
Mediana & 5 & Minimum & 1 \\
Tryb & 4 & Maksimum & 81 \\
Odchylenie standardowe & 19,43123 & Suma & 575 \\
Wariancja próbki & 377,5725 & Licznik & 43 \\
Kurtoza & 5,704824 & Poziom ufności $(95,0 \%)$ & 5,980049 \\
\hline
\end{tabular}

Źródło: opracowanie własne.

\section{5. Źródła finansowania ankietowanych organizacji}

Z przeprowadzonych badań wynika, że najczęściej wykorzystywanym źródłem finansowania działalności organizacji pozarządowych były składki członkowskie. Z tego rodzaju źródeł korzystało ponad $85 \%$ podmiotów. Dotacje z instytucji administracji publicznej wykorzystuje $83 \%$ jednostek, natomiast z darowizn dochody czerpie $71 \%$ organizacji. Spośród badanych tylko co piąta organizacja prowadzi działalność gospodarczą. Wśród innych źródeł finansowania badane organizacje wymieniały m.in. zbiórkę nakrętek, darowizny od członków oraz odsetki od lokat bankowych (tabela 7).

TABELA 7: Udział źródel finansowania działalności badanych organizacji pozarzadowych (\%)

\begin{tabular}{|c|c|c|c|c|c|c|c|c|c|c|}
\hline Źródło & 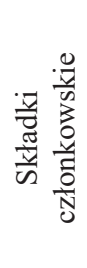 & 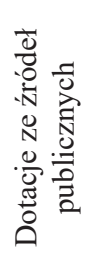 & 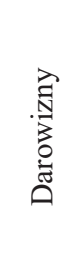 & 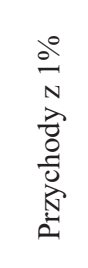 & 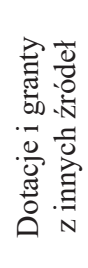 & 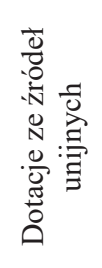 & 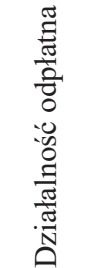 & 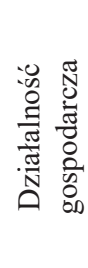 & 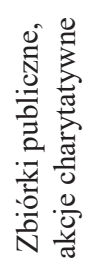 & 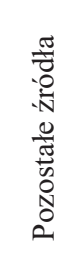 \\
\hline Udział* & 85,06 & 82,76 & 71,26 & 42,53 & 41,38 & 39,08 & 31,03 & 18,39 & 10,34 & 5,75 \\
\hline
\end{tabular}

Objaśnienia: * Możliwy wybór kilku wariantów odpowiedzi.

Źródło: opracowanie własne. 
Większość z badanych organizacji aktywnie poszukuje nowych źródeł finansowania. $\mathrm{O}$ dotacje $\mathrm{z}$ funduszy administracji publicznej występowało ponad $86 \%$ podmiotów, z czego tylko $4 \%$ dofinansowania nie uzyskało (wykres 1). Spośród ankietowanych ok. 80\% ankietowanych podmiotów brało udział w otwartych konkursach, organizowanych przez sektor publiczny i prywatny. Należy przy tym zauważyć, że spośród 69 organizacji biorących udział w konkursach dotacyjnych aż 68 kierowało wnioski do instytucji administracji publicznej, natomiast jedynie 9 podmiotów brało udział w konkursach, które organizowały firmy prywatne. Może to być spowodowane relatywnie niskimi środkami, które przeznaczają przedsiębiorstwa prywatne na projekty realizowane wspólnie z trzecim sektorem.

WYKRES 1. Formy wspótpracy z otoczeniem zewnętrznym

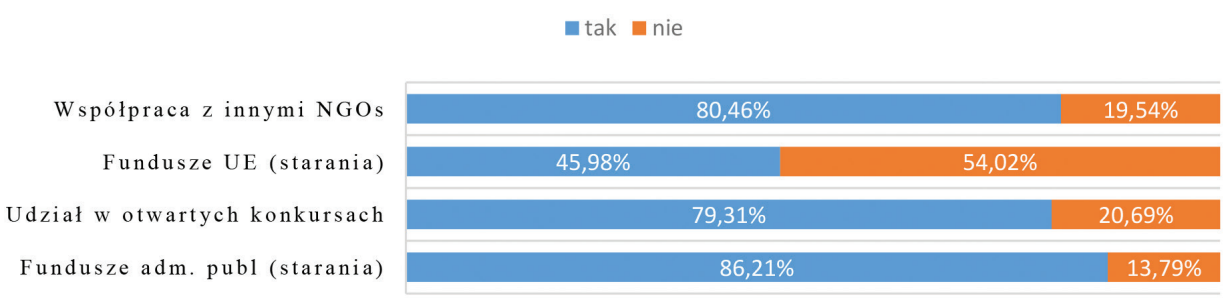

Źródło: opracowanie własne.

W bieżącej działalności sektora pozarządowego bardzo istotne jest pozyskiwanie środków będących w dyspozycji administracji krajowej i samorządowej. Organizacje pozyskują z tego źródła dotacje celowe, realizują zadania zlecone i biorą udział w konkursach na organizację projektów $\mathrm{z}$ dofinansowaniem z funduszy publicznych.

Badane organizacje były dotowane środkami administracji publicznej działającej na szczeblu gminnym, powiatowym, wojewódzkim i centralnym. Spośród organizacji, które otrzymały dofinansowanie z dotacji sektora publicznego, najwyższy odsetek (prawie 75\%) uzyskało dotacje od instytucji działających na gminnym poziomie administracji publicznej. Niemal połowa z NGOs, które wzięły udział w badaniu, pozyskuje środki z funduszy będących w dyspozycji powiatów i województw. Najmniejszy udział (32\% organizacji) otrzymało dotacje z centralnego szczebla finansów publicznych (wykres 2). 
WYKRES 2: Szczeble administracji dotujące badane organizacje pozarządowe (możliwy wybór kilku wariantów odpowiedzi)

$$
\mathrm{n}=75
$$

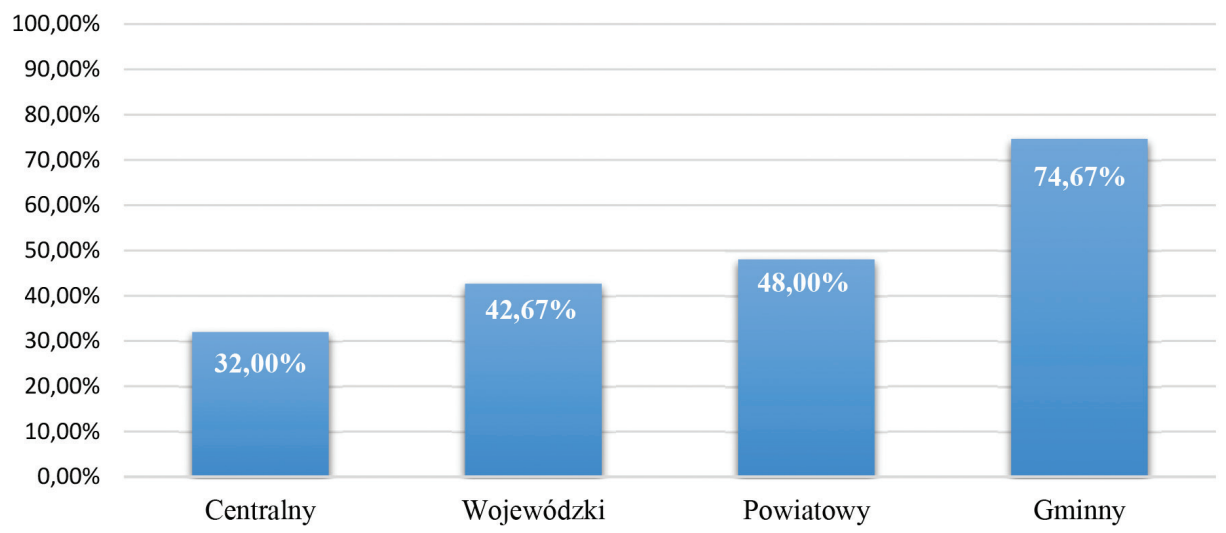

Źródło: opracowanie własne.

Spośród jednostek trzeciego sektora starających się o dotacje z Unii Europejskiej (46\% ankietowanych organizacji) aż 85\% uzyskało dofinansowanie (wykres 3).

WYKRES 3: Dofinansowanie unijne uczestników badania (możliwy wybór kilku wariantów odpowiedzi)

Odsetek organizacji pozarządowych
aplikujących o fundusze unijne

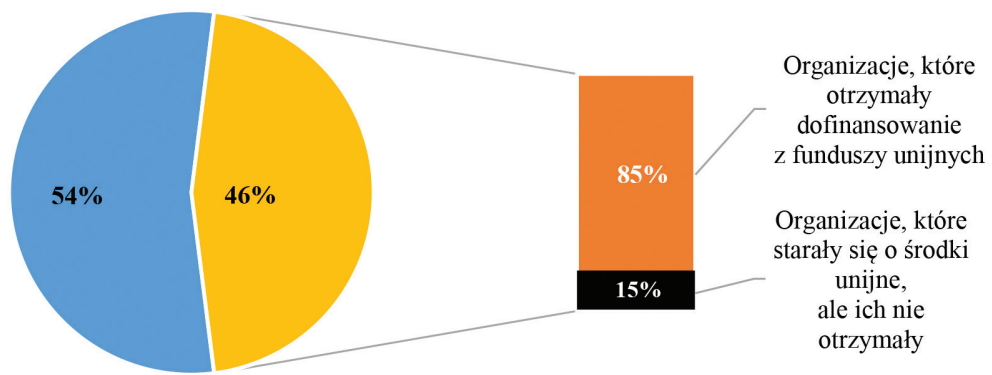

Źródło: opracowanie własne.

Należy jednak zauważyć, że większość organizacji nie aplikuje o środki unijne, co może być spowodowane zarówno skomplikowanymi procedurami, 
związanymi z wnioskowaniem o dotacje, jak i rozbudowaną procedurą sprawozdawczą po zakończeniu realizacji projektu finansowanego ze środków Unii Europejskiej.

\section{Czynniki wpływające na finansowanie NGOs}

Sektor pozarządowy charakteryzuje dążenie do wewnętrznej kooperacji. Ponad $80 \%$ pytanych organizacji współpracuje z innymi NGOs. Ponad $67 \%$ organizacji pozytywnie oceniło relacje z innymi podmiotami sektora, natomiast negatywnie jedynie około 7\% uczestników badania. Średnia odpowiedzi, obliczona za pomocą dyferencjału semantycznego dla współpracy z innymi NGOs, wyniosła 3,73 punktów.

Najniżej przez respondentów oceniona została procedura pozyskiwania funduszy z Unii Europejskiej. Na 5-stopniowej skali Likerta średnia ocen wyniosła 3,08 punktów. Ponad 34\% badanych oceniło pozyskiwanie funduszy unijnych negatywnie, przy czym aż 15,79\% - zdecydowanie negatywnie (wykres 4).

WYKRES 4: Ocena wspótpracy z otoczeniem zewnętrznym

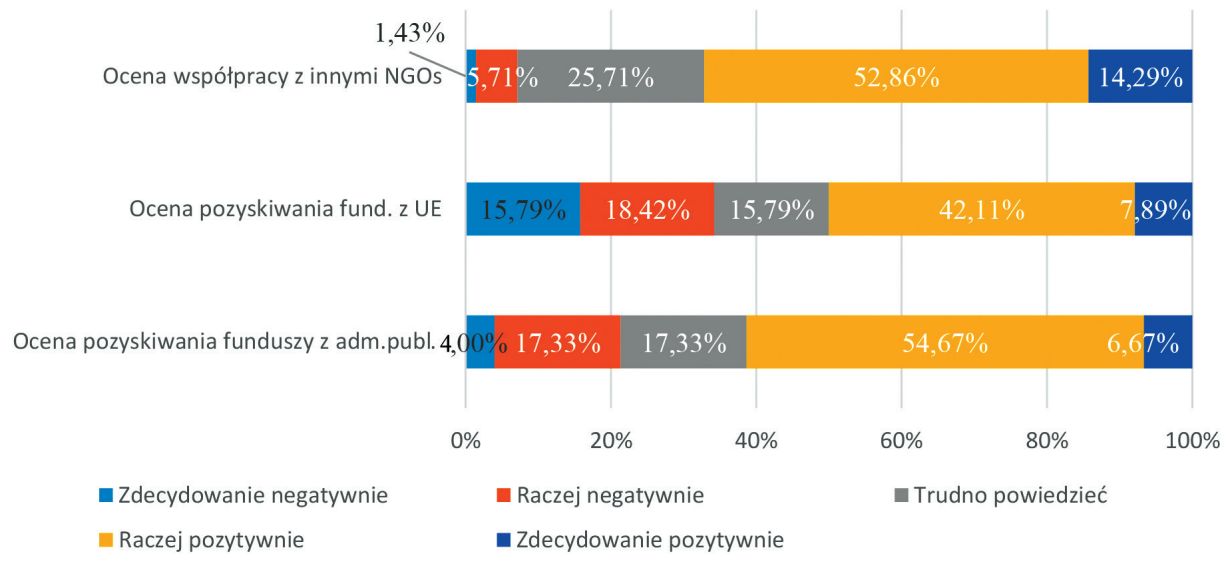

Źr ó dło: opracowanie własne.

W przypadku pozyskiwania źródeł z instytucji administracji publicznej odbiór był w większości przypadków pozytywny. Ponad $61 \%$ badanych organizacji oceniło pozytywnie proces pozyskiwania funduszy z instytucji administracji publicznej. Średnia, liczona za pomocą metody dyferencjału semantycznego, wyniosła 3,43 punktów (wykres 5). 
WYKRES 5: Ocena wspótpracy z interesariuszami zewnętrznymi wedtug skali Likerta

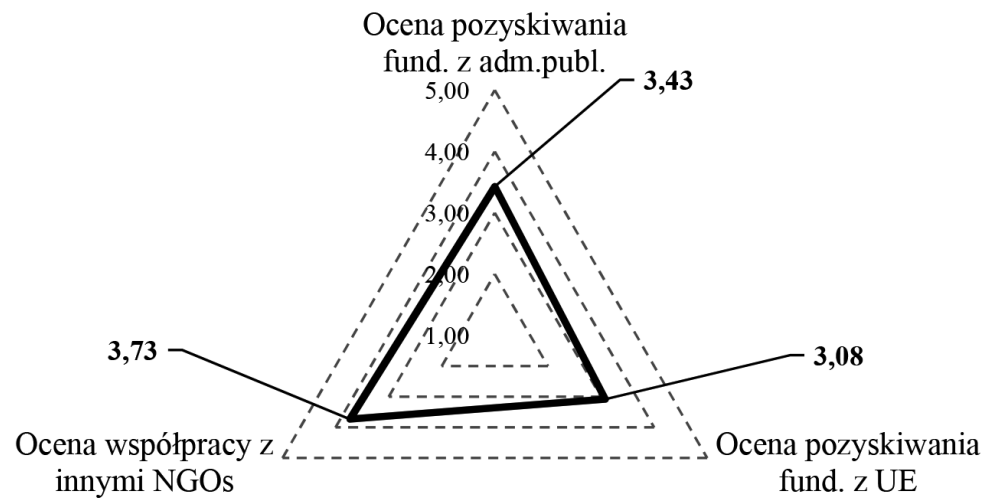

Źródło: opracowanie własne.

Jako główne bariery w procesie pozyskiwania źródeł finansowania organizacje wskazywały trudności związane $\mathrm{z}$ procedurami pozyskiwania funduszy, nadmierną biurokrację (ponad 70\% ankietowanych) oraz skomplikowane wnioski ${ }^{14}$ (prawie 53\% respondentów). Badane podmioty dostrzegają bariery również w konkurencji na rynku starających się o dotacje (ponad 41\%) czy niedoinformowania w kwestii aktualnie organizowanych konkursów (ponad 26\%).

TABELA 8: Bariery pozyskiwania przychodów wedlug respondentów (\%)

\begin{tabular}{|c|c|c|c|c|c|c|c|c|}
\hline 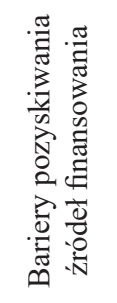 & 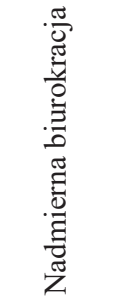 & 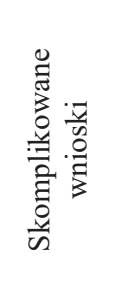 & 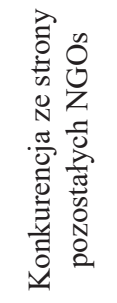 & 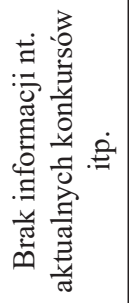 & 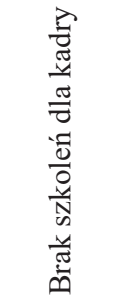 & 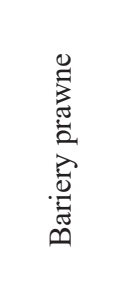 & 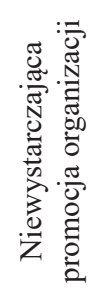 & $\stackrel{\Xi}{\Xi}$ \\
\hline Udział* & $70,11 \%$ & $52,87 \%$ & $41,38 \%$ & $26,44 \%$ & $19,54 \%$ & $16,09 \%$ & $8,05 \%$ & $6,90 \%$ \\
\hline
\end{tabular}

Objaśnienia:

* Możliwy wybór kilku wariantów odpowiedzi.

Źródło: opracowanie własne.

14 Skomplikowane wnioski to takie, które sprawiają problem podczas wypełniania, są niezrozumiałe dla czytelnika, zbyt złożone. 
Poważną barierą wskazywaną przez respondentów był również brak czasu ze strony członków organizacji na starania się o dodatkowe źródła, niedopasowanie konkursów do potrzeb odbiorców oraz ograniczona pula dostępnych środków. Przeciętny ankietowany wskazywał po dwie bariery pozyskiwania przychodów.

Respondentów poproszono o wskazanie działań ułatwiających pozyskiwanie nowych źródeł finansowania dla organizacji pozarządowych. Odpowiedzi zestawiono w tabeli 9. Największa liczba ankietowanych (prawie 45\%) wskazała na indywidualne prośby o datki jako najskuteczniejsze narzędzie, przyczyniające się do wzrostu przychodów. Wysoko oceniona została ponadto skuteczność szkoleń dla personelu i kadry zarządzającej (na które wskazało prawie 38\% organizacji) oraz poszerzanie kontaktów z podmiotami ze sfery biznesu (na to działanie wskazało $37 \%$ badanych). Przeciętny respondent wskazywał dwie odpowiedzi dotyczące przeciwdziałaniu barierom pozyskiwania środków.

TABELA 9: Przeciwdziałanie barierom pozyskiwania środków wedlug ankietowanych (\%)

\begin{tabular}{|c|c|c|c|c|c|c|c|c|}
\hline 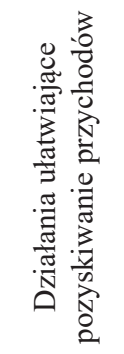 & 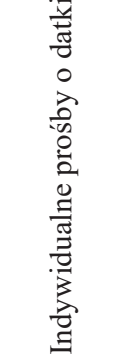 & $\begin{array}{l}\frac{\pi}{0} \\
\frac{0}{0} \\
\frac{\overrightarrow{0}}{N}\end{array}$ & 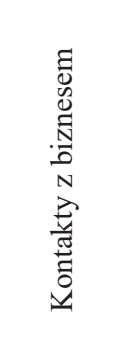 & 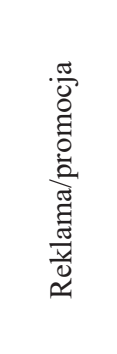 & 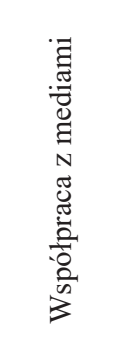 & 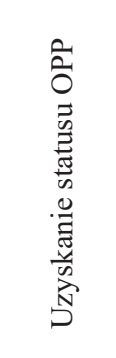 & 号 & 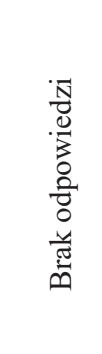 \\
\hline Udział* & $44,83 \%$ & $37,93 \%$ & $36,78 \%$ & $32,18 \%$ & $29,89 \%$ & $28,74 \%$ & $8,05 \%$ & $1,15 \%$ \\
\hline
\end{tabular}

Objaśnienia:

* Możliwy wybór kilku wariantów odpowiedzi.

Źr ódło: opracowanie własne.

Wśród innych możliwości pozyskiwania przychodów badane jednostki wskazywały m.in. na popularyzację idei wspierania trzeciego sektora, podnoszenie świadomości społecznej w tym zakresie poprzez pogadanki czy prelekcje oraz organizowanie pomocy merytorycznej i prawnej przy wypełnianiu wniosków. Podnoszono poza tym postulaty zwiększenia środków publicznych na działalność organizacji pozarządowych. 


\section{Wynik finansowy i przychody organizacji pozarządowych}

Badane organizacje osiągnęły w 2016 r. zróżnicowany poziom przychodów. Najniższe przychody (poniżej 1 tysiąca zł) zaobserwowano w przypadku prawie $6 \%$ analizowanych podmiotów sektora NGOs. Maksymalne przychody w badanej próbie wyniosły 5228 597,98 zł. Największy udział (prawie 42\%) miały organizacje, których przychody znajdowały się w przedziale od 10 do 100 tysięcy zł (wykres 6).

WYKRES 6: Przychody badanych organizacji w $2016 r$.

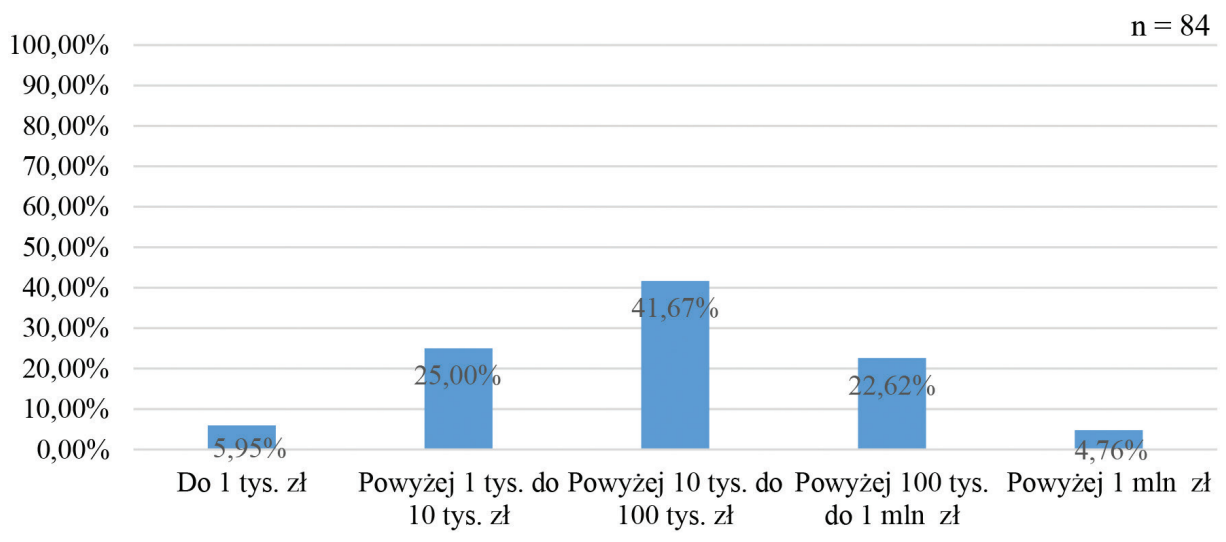

Źródło: opracowanie własne.

Przeprowadzone badania wykazały, że kondycja finansowa jest oceniana jako dobra. Badane organizacje w 2016 r. w większości przypadków osiągnęły wzrost wyniku finansowego w stosunku do roku poprzedniego (prawie $60 \%$ podmiotów). Niespełna 14\% ankietowanych jednostek odnotowało stratę (wykres 7).

Podmioty sektora NGOs odnotowały w niemal 44\% wzrost liczby źródeł przychodów w 2016 r. w stosunku do roku poprzedniego. Na tym samym poziomie, co w roku 2015 liczba źródeł finansowania utrzymała się u ponad 32\% organizacji. Jedynie około $24 \%$ badanych podmiotów zadeklarowało spadek liczby źródeł przychodów (wykres 8). 
WYKRES 7: Dynamika wyniku finansowego

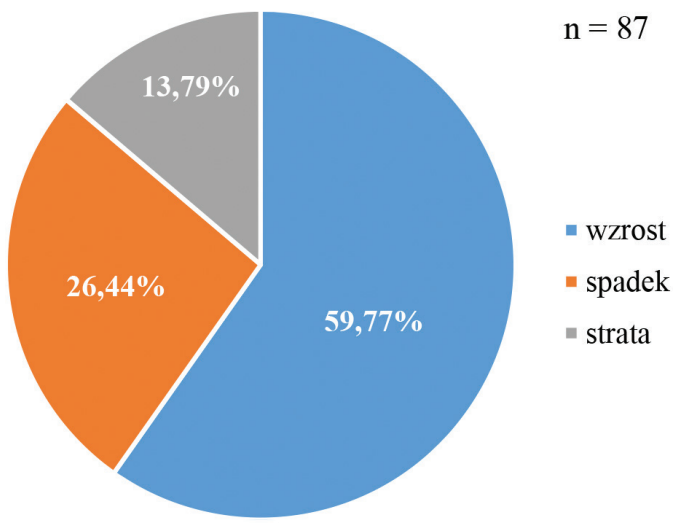

Źr ódło: opracowanie własne.

WYKRES 8: Przychody w roku 2016 w stosunku do roku poprzedniego

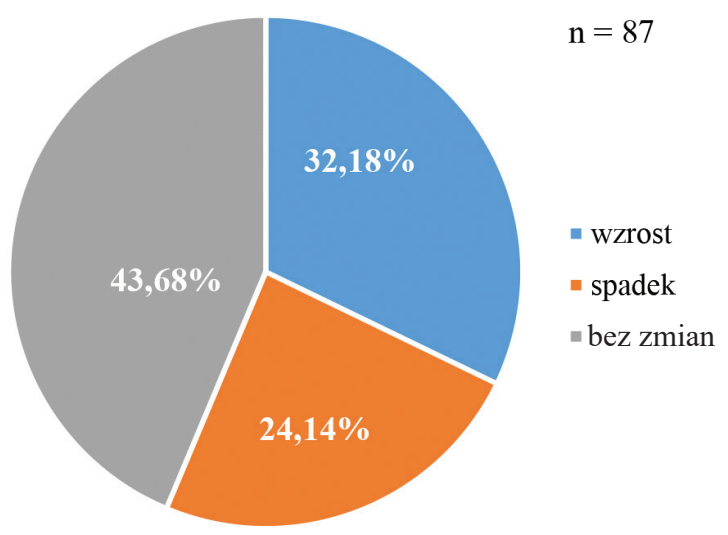

Źr ódło: opracowanie własne.

W celu określenia czynników wpływających na wysokość przychodów i kondycję finansową organizacji trzeciego sektora weryfikacji poddano 4 hipotezy badawcze:

1. Wysokość przychodów organizacji pozarządowej zależy od posiadania statusu OPP;

2. Wynik finansowy organizacji pozarządowej zależy od zmiany liczby źródeł przychodów w stosunku do roku poprzedniego; 
3. Przychody organizacji pozarządowej zależą od dywersyfikacji źródeł przychodów;

4. Przychody organizacji pozarządowej zależą od okresu aktywności.

\section{Hipoteza 1:}

$\mathrm{H}_{0}$ : Wysokość przychodów organizacji pozarządowej nie zależy od posiadania statusu OPP.

$\mathrm{H}_{1}$ : Wysokość przychodów organizacji pozarządowej zależy od posiadania statusu OPP.

Wartość p statystyki obliczona w teście dokładnym Fishera jest niższa od przyjętego poziomu istotności $\alpha=0,05$; a zatem można uznać wyniki badania za istotne statystycznie i odrzucić hipotezę zerową na rzecz hipotezy alternatywnej mówiącej, że wysokość przychodów organizacji pozarządowej zależy od posiadania statusu OPP. Siłę związku korelacyjnego obliczono za pomocą współczynnika zbieżności T-Czuprowa. Wielkość ta wyniosła 0,83 ; a zatem pomiędzy wielkością przychodów organizacji pozarządowej a posiadaniem przez nią statusu OPP istnieje bardzo wysoka zależność korelacyjna.

Do oceny natężenia korelacji między badanymi zmiennymi wykorzystano ponadto współczynnik determinacji. W ponad $68 \%$ zmienność wielkości przychodów organizacji pozarządowych określona jest posiadaniem przez nie statusu OPP.

\section{Hipoteza 2:}

$\mathrm{H}_{0}$ : Wynik finansowy organizacji pozarządowej nie zależy od zmiany liczby źródeł przychodów w stosunku do roku poprzedniego.

$\mathrm{H}_{1}$ : Wynik finansowy organizacji pozarządowej zależy od zmiany liczby źródeł przychodów w stosunku do roku poprzedniego.

Wartość p obliczona za pomocą testu dokładnego Fishera jest niższa od poziomu istotności $\alpha=0,05$; a więc można uznać wyniki za istotne statystycznie i odrzucić hipotezę zerową na rzecz hipotezy alternatywnej mówiącej, że wynik finansowy organizacji pozarządowej zależy od zmiany liczby źródeł przychodów w stosunku do roku poprzedniego. Siła związku korelacyjnego obliczona za pomocą współczynnika zbieżności T-Czuprowa wyniosła 0,27; a zatem pomiędzy wynikiem finansowym organizacji pozarządowej a zmianą liczby źródeł przychodów w stosunku do roku poprzedniego istnieje słaby związek korelacyjny. 


\section{Hipoteza 3:}

$\mathrm{H}_{0}$ : Przychody organizacji pozarządowej nie zależą od dywersyfikacji źródeł przychodów.

$\mathrm{H}_{1}$ : Przychody organizacji pozarządowej zależą od dywersyfikacji źródeł przychodów.

Wartość $\mathrm{p}$ statystyki obliczona $\mathrm{w}$ teście dokładnym Fishera jest niższa od przyjętego poziomu istotności $\alpha=0,05$; a zatem można uznać wyniki badania za istotne statystycznie i odrzucić hipotezę zerową na rzecz hipotezy alternatywnej mówiącej, że przychody organizacji pozarządowej zależą od dywersyfikacji źródeł przychodów. Siłę związku korelacyjnego zmierzono za pomocą współczynnika korelacji T-Czuprowa, którego wielkość wyniosła 0,19; można zatem stwierdzić, że pomiędzy wielkością przychodów organizacji pozarządowej a liczbą źródeł finansowania istnieje bardzo słaby związek korelacyjny.

\section{Hipoteza 4:}

$\mathrm{H}_{0}$ : Przychody organizacji pozarządowej nie zależą od okresu aktywności.

$\mathrm{H}_{1}$ : Przychody organizacji pozarządowej zależą od okresu aktywności.

Wartość p statystyki obliczona za pomocą testu dokładnego Fishera jest wyższa od przyjętego poziomu istotności $\alpha=0,05$; a zatem nie można uznać wyników za istotne statystycznie i nie ma podstaw do odrzucenia hipotezy zerowej mówiącej, że przychody organizacji pozarządowej nie zależą od okresu działalności.

Przeprowadzone badania ankietowe oraz ich analiza statystyczna pozwoliły na pozytywną weryfikację hipotezy o istotności posiadania przez organizacje pozarządowe statusu OPP, dywersyfikacji źródeł przychodów oraz dążenia do zwiększania ich liczby. Nie udało się natomiast zweryfikować hipotezy o zależności pomiędzy wielkością przychodów a doświadczeniem organizacji na rynku NGOs.

\section{Podsumowanie}

W celu identyfikacji przyczyn mających wpływ na zwiększenie przychodów i polepszenie wyniku finansowego podmiotów trzeciego sektora przeprowadzono badania ankietowe, które stanowiły podstawę weryfikacji hipotez badawczych.

Udowodniono hipotezy zakładające zależność wysokości przychodów organizacji pozarządowych od dywersyfikacji źródeł finansowania, posiadania statusu OPP oraz między wynikiem finansowym a zwiększaniem zainteresowa- 
nia nowymi możliwościami poszukiwania przychodów. Nie udało się natomiast udowodnić hipotezy zakładającej zależność pomiędzy doświadczeniem organizacji (mierzonej długością prowadzonej działalności) a wielkością przychodów.

Istnieje duża nierównomierność rozmieszczenia zasobów w trzecim sektorze. NGOs to zarówno duże organizacje, dysponujące znacznymi budżetami, jak i niewielkie, lokalne podmioty o małych przychodach. Trudności w pozyskiwaniu środków finansowych upatrywane są przede wszystkim w kontaktach $\mathrm{z}$ administracją publiczną, co związane jest ze skomplikowaną procedurą składania wniosków dotyczących dotacji na finansowanie działalności. Istotne jest zatem ułatwienie trybów składania wniosków na realizację projektów podejmowanych przez organizacje lokalne. Trudności te mogłyby być zniwelowane w pewnym stopniu pogłębianiem kompetencji personelu organizacji pozarządowych, jednak wiele z NGOs nie ma funduszy na niezbędne szkolenia. Pozytywnie oceniono natomiast współpracę z innymi podmiotami trzeciego sektora.

\section{Bibliografia}

\section{Akty prawne}

Ustawa z dnia 6 kwietnia 1984 r. o fundacjach, z późniejszymi zmianami, Dz.U. z 2018 r., poz. 1491.

Ustawa z dnia 7 kwietnia 1989 r. - Prawo o stowarzyszeniach, z późniejszymi zmianami, Dz.U. z 2019 r., poz. 713.

Ustawa z dnia 24 kwietnia 2003 r. o działalności pożytku publicznego i o wolontariacie, z późniejszymi zmianami, Dz.U. z 2019 r., poz. 688.

\section{Opracowania}

Bogacz-Wojtanowska E., Istota i podstawowe zasady funkcjonowania organizacji pozarzadowych, w: E. Bogacz-Wojtanowska, S. Wrona (red.), Zarządzanie organizacjami pozarzadowymi, Wydawnictwo Instytutu Spraw Publicznych Uniwersytetu Jagiellońskiego, Kraków 2016, s. 11-29.

Bogacz-Wojtanowska E., Zarządzanie organizacjami pozarządowymi na przykładzie stowarzyszeń krakowskich, Wydawnictwo Uniwersytetu Jagiellońskiego, Kraków 2006, s. 27-28.

Dyczkowski T., Wplyw źródel finansowania na planowanie i kontrolę w organizacjach korzystajacych z pomocy publicznej, Prace Naukowe Uniwersytetu Ekonomicznego we Wrocławiu 2016/424, s. 72-85.

Galor Z., Kalinowski S., Kujaczyński T., Rola ekonomii pomocy w przeciwdziałaniu kluczowemu działaniu w globalizacji, Roczniki Ekonomiczne Kujawsko-Pomorskiej Szkoły Wyższej w Bydgoszczy 2013/6, s. 91-104.

Grzelońska U., Rola sektora non profit w polskiej gospodarce, Studia Ekonomiczne 2011/4, s. 326. 
Hausner J., Organizacje pozarzadowe - trzeci sektor współczesnego społeczeństwa, Zeszyty Naukowe Akademii Ekonomicznej w Krakowie 2006/714, s. 5-21.

Hausner J., Laurisz N., Czynniki krytyczne tworzenia przedsiębiorstw społecznych. Przedsiębiorstwo społeczne. Konceptualizacja, w: J. Hausner (red.), Przedsiębiorstwa społeczne w Polsce. Teoria i praktyka, Wydawnictwo Małopolska Szkoła Administracji Publicznej Uniwersytetu Ekonomicznego w Krakowie, Kraków 2008, s. 9-31.

Kaczocha W., Sikora J., Gospodarcze społeczeństwo obywatelskie - podmioty ekonomii społecznej, Studia Oeconomica Posnaniensia 2015/7, s. 57-71.

Kalinowski S., Ekonomia społeczna?, w: Dylematy wspótczesnej polityki społecznej, Z warsztatu badawczego Katedry Nauk Społecznych. Rok dziewiąty, Poznań 2007, s. 20-29.

Kietlińska K., Rola trzeciego sektora w społeczeństwie obywatelskim, Wydawnictwo Difin, Warszawa 2010, s. 91.

Leś E., Nałęcz S., Potencjat ekonomiczny i spoleczny sektora non-profit w Polsce. Wybrane wyniki badań międzynarodowych sektora non-profit, w: P. Gliński, B. Lewenstein, A. Siciński (red.), Samoorganizacja społeczeństwa polskiego: trzeci sektor, Wydawnictwo Instytutu Filozofii i Socjologii PAN, Warszawa 2002, s. 13-31.

Lorentowicz K., Kalinowski S., Wyduba W., Syntetyczny wskaźnik finansowania organizacji pożytku publicznego, Handel Wewnętrzny 2018/6(377)/I, s. 273-286.

Marcysiak T., Prus P., Life strategies of rural inhabitants of unfixed economic function, Pro-ceedings of the 26th International Scientific Conference Agrarian Perspectives XXVI "Competi-tiveness of European Agriculture and Food Sectors", Czech University of Life Sciences Prague, Faculty of Economics and Management 2017, s. 212-218.

Moroń D., Trzeci sektor w teorii wielosektorowej polityki społecznej, Wrocławskie Studia Politologiczne 2013/15, s. 7-17.

Ninacs W.A., A Review of the Theory and Practice of Social Economy, SRDC Working, Paper Series 2002/02/02, s. 7.

Sałustowicz P., Soziale Arbeit und Empowerment - einige kritische Bemerkungen zur Suche nach einer politischen Sozialen Arbeit, w: K. Böller, P. Hansbauer, B. Hansenjürgen, S. Langenohl (Hrsg.), Die Produktivität des Sozialen - den sozialen Staat aktivieren, VS Verlag für Sozialwis - senschaften, Wiesbaden, s. 187-196.

Schmidt J., Rozwój organizacji pozarządowych. Teoria i praktyka, Wydawnictwo Akademickie Sedno, Warszawa 2012, s. 15.

Zwęglińska-Galecka D., Gentryfikacja wsi i jej zasięg, Wieś i Rolnictwo 2019/183/2, s. 57-87.

\section{Strony internetowe}

www.ngo.pl; stan na 2.12.2019 r. 
Katarzyna LORENTOWICZ, Sławomir KALINOWSKI, Weronika WYDUBA

\title{
FUNDING FOR RURAL NGOs
}

\begin{abstract}
Background: Non-governmental organizations (NGOs) form the third sector of the economy alongside the public and private sectors. They are not profit-oriented, but they must actively seek sources of financing for their activities.

Research purpose: The purpose of the article is to identify the factors that are responsible for the efficiency of NGO financing based on an analysis of the sources of NGO financing in rural areas compared to urban areas.

Methods: The theoretical part discusses the concept of the third sector, the legal basis for its functioning, the specifics of NGOs that operate in rural areas, and Public Benefit Organizations (PBOs). In the empirical part, the research hypotheses were verified, which assumed the dependence of the amount of revenues and financial results on the NGOs' PBO status, their experience, quantity, and diversification of revenue sources. The empirical analysis is based on a survey.

Conclusions: Hypotheses were proved regarding the dependence of the amount of NGO revenues on the diversification of sources of financing, having PBO status, and between the financial result and increasing interest in new revenue search opportunities. However, the hypothesis regarding the relationship between an organization's experience (measured by the length of the business) and the amount of revenue was not proved.
\end{abstract}

Keywords: third sector, NGOs, funding sources. 